\title{
The Impact of Capital Structure on Profitability in the Telecommunication Industry Listed on the Indonesian Stock Exchange
}

\author{
I Wayan Sima Wiyasa* \\ Universitas Bina Darma \\ Indonesia \\ basyith@binadarma.ac.id \\ Abdul Basyith \\ Universitas Bina Darma \\ Indonesia
}

\begin{abstract}
The purpose of this study is to find the effect of capital structure on profitability in the telecommunication industry company at Indonesian Stock Exchange. Variables that are used to measure the capital structure are Debt to Asset Ratio (DAR), Debt to Equity Ratio (DER) and Longterm Debt Equity Ratio (LTDtER). Meanwhile, the variable used to measure company's financial performance is profitability ratio such as, Return On Equity (ROE). The population of this study is Telecommunications Company at Indonesian Stock Exchange with study period 2009-2018. The sampling method employed is purposive sampling in total 5 companies with panel data analysis method. The result proves that capital structure's variable DAR has negative and significant effect on ROE. Capital structure's variable DER has negative and significant effect on ROE. Meanwhile, capital structure's variable LTDtER has positive but not significant effect on ROE.
\end{abstract}

Keywords-Debt to Equity Ratio (DER); Debt to Asset Ratio (DAR); Long-term Debt Equity Ratio (LTDtER)

\section{INTRODUCTION}

In the current millennial era, the development of information technology makes it easier for everyone to integrate with others and makes it easier for everyone to get information about various aspects of life, one of which is the economic and business aspects. In real time, one of the fast growing business sectors is the telecommunications industry. Telecommunications companies were chosen as research objects because the development of the telecommunications industry today is increasing rapidly. There are many consumer demands for new telecommunications operator facilities popping up with various types and supporting features as the advantages of their products. In running this type of business as a service company, telecommunications require a source of funds. Sources of funds can be derived from sources of the loan capital and sources of own capital.
One of the industries that develop at this time is the telecommunications industry. The telecommunications industry is an industry that has a major influence on the smooth running of economic and business activities, with this all information can be obtained quickly and precisely. There are 300 million numbers recorded in the telecommunications industry that are growing very rapidly in the country, although not all reflect unique subscribers or different customers. On the other hand telecommunications services currently available are still focused on voice communication services, SMS, and some data that tends to increase, both in numbers and percentages [1]. With the advancement or development of increasingly sophisticated technology, there are many communities in Indonesia, which conducts online business through several social media applications such as Facebook, Instructor, Shopee, Bukalapak, etc. Indeed variety of businesses, besides that through social media can also be a promotional or advertising tool so that people easily find out and are interested. Instagram active users in Indonesia have reached 45 million active users in 2017 in the first quarter while Facebook users in Indonesia reach 130 million. The higher level of human needs demands fast telecommunications services too, inseparable from space and distance that is why telecommunications services become an inseparable need. This increased growth will certainly increase the company's revenue, and reflect that the company's performance is good.

In general, there are 11 telecommunications industry companies in Indonesia, namely PT Bali Towerindo, Bakrie Telecom Tbk, Elang Mahkota Teknologi, XL Axiata Tbk, Smartfren Telecom Tbk, core Bangun Sejahtera, Indosat Tbk, Infracom Innovations, Tunas Pratama Solutions, PT Tower Bersama Infrastructure, and Telekomunikasi Indonesia (Persero) Tbk, but there are only five companies registered in the telecommunications sector on the Indonesia Stock Exchange (IDX), using telecommunications networks, namely Telekomunikasi Indonesia (Persero) Tbk, Indosat Tbk, Smartfreen Telecom Tbk, Bakrie Telecom Tbk, Xl Axiata 


\section{FIGURE 1 DEBT TO EQUITY RATIO (DER)} the following table below:

TABLE 1. TELECOMMUNICATION'S PROVIDER.

\begin{tabular}{|l|l|l|}
\hline No. & Provider & Number of Consumer \\
\hline 1 & Telkomsel & 139.934 .665 \\
\hline 2 & Indosat Ooredo & 100.538 .309 \\
\hline 3 & Smartfren Telecom & 588.086 \\
\hline 4 & XL Axiata & 42.362 .769 \\
\hline 5 & 3 Tri & 12.782 .993 \\
\hline
\end{tabular}

Source: Ministry of Communication and Information, 2019.

The most dominant companies that make good contributions from urban areas to rural areas are cellular networks from PT. Telekomunikasi Indonesia (Persero) Tbk, with 140 million cellular subscribers, and 110,381 3G / 4G mobile network with 29,061 towers. To maintain the condition of the company in order to survive (survival) the company must maintain financial structure and capital structure in order to remain optimal. Therefore financial managers must be careful and careful in determining the expected capital structure of the company so that it can add or increase a company's value and be superior in the face of competition. Therefore, to face any competition and finance its operational activities, every company must need funds or capital. These funds can be obtained from various sources, both from the company's capital (own capital) or from outside the company (foreign capital). From most companies, the source of funds from their own capital is often felt to be lacking, due to the limited funds owned by the internal company. As a result of these limitations, many companies prefer debt as a source of funding because it is not permanent and cheaper than having to issue new shares. That is because if issuing new shares will increase the capital spent. Sources of internal company funds can come from retained earnings and depreciation, while external sources of funds come from debt and equity. Effect of capital structure on the acquisition or rate of profit in the company. The reason is since the ownership of a good capital structure will affect the profitability (level of profit) of the company.

The following table and graph are presented below which contain the capital structure of this variable, namely Debt to Equity Ratio (DER) in the 2016-2018 period in this study to see how it affects earnings.

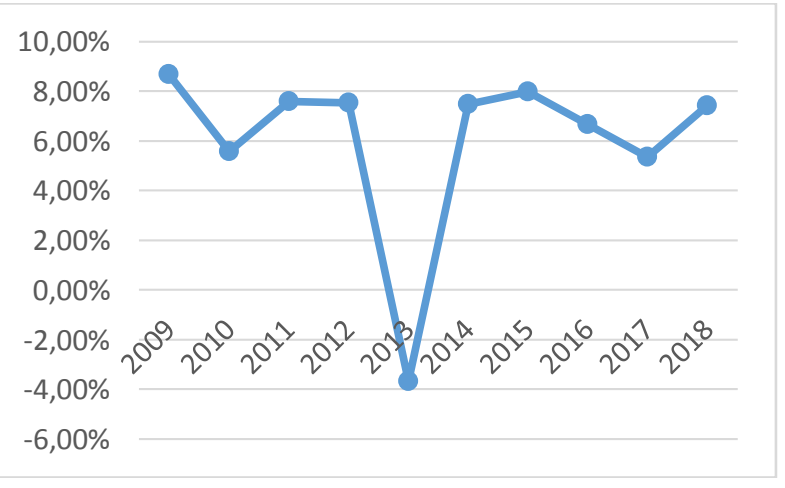

Overall, the average on Debt to Equity Ratio (DER) experienced ups and downs in 2013-2018 of -3.67 to 7.42 , this indicates the amount of capital from outsiders, the company has a higher risk to the company's liquidity, which the effect will have a negative impact on the profitability of a company. Every company certainly has a goal to generate profits or is called with great profitability for the company and investors. The notion of profitability ratios is ratios that assess a company's ability to make profits [2]. This ratio also provides a measure of the effectiveness of a company's management. The following table and graph are presented below which contain the profitability of Return on Equity (ROE).

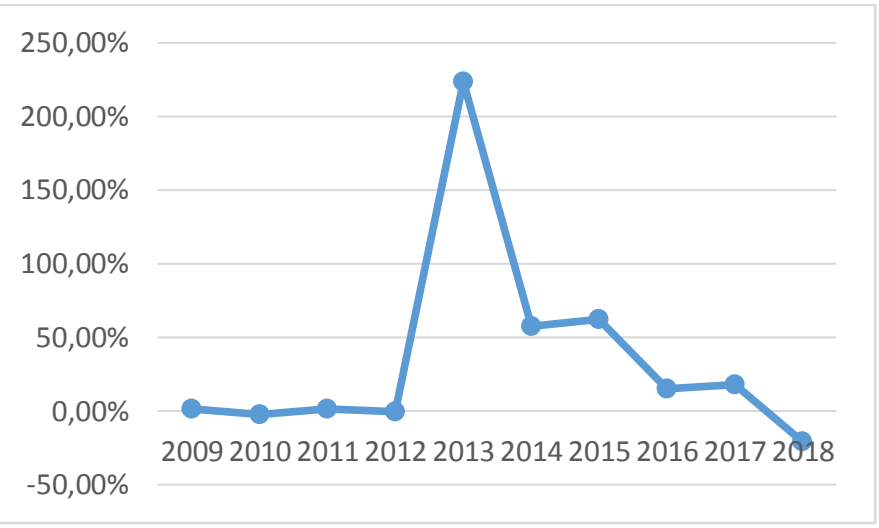

FIGURE 2 RETURN ON EQUITY (ROE)

Overall for three years, the average fluctuating Return on Equity (ROE), which in 2009 was 1.04 in 2013, experienced an increase of 1.04 and in 2018 experienced a significant decrease in -21.06 . The success rate of a company can be seen from the small Debt to Equity Ratio (DER) and the amount of Return on Equity (ROE) because if Debt to Equity Ratio (DER) is large then the company has a higher risk to the company's liquidity, so the main effect will decrease a corporate profit. Empirical data about the DER variable to ROE can be seen in the table above shows that the average value of DER in 2018 is 7.42 . This will have an impact on ROE in table 3, the average value in 2018 of $-21.06 \%$. This indicates that the company's ability to generate profits by utilizing the equity it has in 2018 has a very declining performance.

The importance of telecommunications sector companies because the telecommunications sector is one sector that has an important role in achieving economic growth in Indonesia and the amount of employment, considering that every activity related to the economy must be done quickly, the telecommunications sector must also be upgraded to become more qualified and increasingly to develop. By increasing or decreasing the level of quantity and quality of telecommunications automatically as well as the level of income of the Indonesian economy and the amount of labor absorption will be greatly influenced by the 
telecommunications sector itself. Thus in solving the problems experienced by the company, capital structure that can be optimal profitability is needed to achieve profits that are designed as a company goal. Therefore, this study will analyze the effect of capital structure (DAR, DER LTDtER) on profitability (ROE) on telecommunications industry companies listed on the Indonesia Stock Exchange (BEI) Period 2016-2018".

\section{LITERATURE REVIEW}

In this study, the capital structure uses a solvency ratio, which means that the ratio is used to measure the extent to which the company's assets are financed with debt. The ratios used in this study are Debt to Equity Ratio (DER), Debt to Asset Ratio (DAR), and Long Term Debt to Equity Ratio (LTDtER). DAR is used to measure the ratio between total debt to total assets [2]. DER is used to measure how much the company's assets are financed by creditors [2]. LTDtER is used to measure the ratio between long-term debt with own capital [2]. In the study of profitability ratio measurement using the Return on Equity (ROE) formula. Return on Equity is used to measure the effectiveness of a company in generating profits by utilizing the equity it has [2].

The relationship of Debt to Equity Ratio (DER) to Return on Assets (ROE) in theory according to experts: high and low Debt to Equity Ratio (DER) will affect the level of achievement of Return on Equity (ROE) achieved by the company. The higher the Debt to Equity Ratio (DER) indicates the greater the company's burden on outsiders, this is very possible decreasing Return on Equity (ROE), because the level of dependence with outsiders is higher. So the influence between DER and ROE is negative [3]. Capital structure is a balance between the amount of short-term debt is permanent, long-term debt, preferred sham and common stock [3]. Capital structure is the comparison between foreign capital or the amount of debt with own capital.

Capital structure is a comparison between foreign capital or the amount of debt with own capital [3]. Capital structure is a balance of the amount of short-term debt that is permanent, long-term debt, preferred shares and ordinary shares [4]. From some understanding of capital structure according to the experts above, I can conclude that capital structure is a mix or comparison between foreign capital and own capital used by companies to finance their assets. There are 3 ratios used for capital structure that is debt to asset ratio, debt to equity ratio and long term to equity ratio.

The DAR DER has a significant effect on ROA [5], while DAR DER LDER has a negative but not significant effect on ROA [6]. DER has a negative effect, DAR has a positive and significant impact, and LDER has a positive and significant effect on ROE profitability [7] while the results of a research conducted states that the short-term debt yield negative and significant coefficient for profitability confirms the peckingorder theory [8]. On the other hand, the results of a research conducted DAR has a positive and significant effect DER has a significant negative effect EAR has a positive but not significant effect on ROE [9]. The results of a research conducted states that CAR and DAR have a significant negative effect, DER has a significant positive effect on ROE [10].

\section{RESEARCH METHODOLOGY}

This type of research used in this research is explanatory research with quantitative methods. The population in this study is the telecommunications industry companies listed on the Stock Exchange which numbered 5 companies. The sampling technique used by researchers in this study was purposive sampling, which is a method of selecting nonrandom samples whose information was obtained using certain considerations in order to obtain 5 companies. The data analysis technique used is descriptive analysis. This research involves a variety of data testing with the help of the SPSS program, namely: 1) a classic assumption test consisting of a normality test, a multicollinearity test, an autocorrelation test, and a heteroscedasticity test; 2) multiple regression analysis, 3) $\mathrm{F}$ test, and 4) $t$ test and determination test [11].

\section{RESULTS AND DISCUSSION}

From Table 2, it can be explained as follows. The Debt to Asset Ratio (DAR) variable has an average value of 1.8126 percent and the standard deviation is 4.23582 percent. The Debt To Equity Ratio (DER) variable, has an average value of 1.2218 percent and a standard deviation of 2.08349 percent. The Long Term Debt to Equity Ratio (LDER) variable has an average value of 0.1936 percent and the standard deviation is 3.30861 percent. The profitability variable (ROE) has an average value of 7.0791 percent and the standard deviation is 43.69677 percent. The four variables are calculated using the amount of data used by 50 periods

TABLE 2. DESCRIPTIVE STATISTICS

\begin{tabular}{|l|l|l|l|}
\hline & Mean & Std. Deviation & N \\
\hline ROE & 7,0791 & 43,69677 & 50 \\
\hline DAR & 1,8126 & 4,23582 & 50 \\
\hline DER & 1,2218 & 2,08349 & 50 \\
\hline LTDtER & 0,1936 & 3,30861 & 50 \\
\hline
\end{tabular}

Table 3 illustrates the results of normality testing after the outlier data has been released. The test results using the Kolmogorov Smirnov test show that all variables have values above 0.05 , where the ROE variable has a value of 0.70 , the DAR variable has a value of 0.089 and the DER variable has a value of 0.200 and the LTDtER variable has a value of 0.200 , so indicates that the data used for the four variables are normally distributed.

TABLE 3. NORMALITY TEST

\begin{tabular}{|l|l|l|l|}
\hline & \multicolumn{3}{|l|}{ Kolmogorov-Smirnov } \\
\hline & Statistic & $d f$ & Sig. \\
\hline ROE & 0,195 & 18 & 0,070 \\
\hline
\end{tabular}




\begin{tabular}{|l|l|l|}
\hline LTDtER & 0,840 & 1,191 \\
\hline
\end{tabular}

\begin{tabular}{|l|l|l|l|}
\hline DAR & 0,189 & 18 & 0,089 \\
\hline DER & 0,156 & 18 & 0,200 \\
\hline LTDtER & 0,120 & 18 & 0,200 \\
\hline
\end{tabular}

$*$ This is a lower bound of the true significance

a. Lilliefors Significance Correction

Table 4 illustrates the results of multiple regression where the ROE variable is the dependent variable. The results of the regression are as follows:

\section{ROE: 6,823 -2,495DAR -20,917DER + 1,736LTDtER}

Based on the regression equation above, it can be explained as follows: The DAR variable has a negative coefficient of 2,495 , this illustrates that if DAR gets an increase of one percent then profitability will decrease by 2,495 percent and vice versa. Whereas the DER variable has a regression coefficient with a negative sign of -20.917 percent, this shows that if the DER variable increases by one percent then profitability will experience a decrease of 20,917 percent and vice versa. The LTDtER variable has a regression coefficient with a positive sign of 1.736 , this indicates that if the LTDtER variable rises by one percent then the profitability variable will increase by 1.736 percent.

TABLE 4. REGRESSION RESULT

\begin{tabular}{|l|l|l|l|}
\hline \multirow{2}{*}{ Model } & \multicolumn{2}{|l|}{ Unstandardize Coefficients } & $\begin{array}{l}\text { Standardize } \\
\text { Coefficient }\end{array}$ \\
\cline { 2 - 4 } & Beta & Std. Error & Beta \\
\hline 1 (Constant) & 38,823 & 3,599 & \\
\hline DAR & $-2,495$ & 0,670 & $-0,242$ \\
\hline DER & $-20,917$ & 1,474 & $-0,997$ \\
\hline LTDtER & 1,736 & 0,885 & 0,131 \\
\hline
\end{tabular}

a. Dependent Variable: ROE

The heteroscedasticity test is using the Glejser Test. The test results as illustrated in table 5 show that all results have a value of more than 0.05 . It can be concluded that the regression model used is not detected or there is no problem with heteroscedasticity.

TABLE 5. HETEROSCEDASTICITY TEST

\begin{tabular}{|c|c|c|c|}
\hline \multirow[t]{2}{*}{ Model } & \multicolumn{2}{|c|}{ Unstandardize Coefficients } & \multirow[t]{2}{*}{ Sig. } \\
\hline & Beta & Std. Error & \\
\hline 1 (Constant) & 14,364 & 2,457 & 0,000 \\
\hline DAR & $-0,354$ & 0,458 & 0,443 \\
\hline DER & $-0,670$ & 1,006 & 0,509 \\
\hline LTDtER & 0,623 & 0,604 & 0,308 \\
\hline
\end{tabular}

Table 6 illustrates the results of multicollinearity testing. The basis for multicollinearity test decision making is by looking at Tolerance and VIF values. If the tolerance value is greater than 0.10 , it means that multicollinearity does not occur. If the VIF value is smaller than 10.00 then it means that there is no multicollinearity.

\begin{tabular}{|c|c|c|}
\hline \multirow[t]{2}{*}{ Model } & \multicolumn{2}{|c|}{ Collinearity } \\
\hline & Tolerance & $V I F$ \\
\hline DAR & 0,906 & 1,104 \\
\hline DER & 0,767 & 1,304 \\
\hline
\end{tabular}

In Table 7 illustrates the results of the Autocorrelation test. The multicollinearity test value can be seen from the value of Durbin Watson. The Durbin Watson value obtained is 1,896 . These results are then compared to the lower and upper limit values, that is $=\mathrm{du}<\mathrm{dw}<4-\mathrm{dl}$. This value when compared to the results obtained as follows $=1.6739<1.896<2.5794$. It can be concluded that there is no autocorrelation between independent variables so that the model is feasible to use. From the three classical assumption tests used, it shows that the regression results can be used to create an equation model.

TABLE 7. AUTOCORRELATION TEST

\begin{tabular}{|l|l|l|l|l|}
\hline Model & R & R Square & $\begin{array}{l}\text { Adjusted R } \\
\text { Square }\end{array}$ & $\begin{array}{l}\text { Durbin- } \\
\text { Watson }\end{array}$ \\
\hline 1 & 0,182 & 0,033 & $-0,030$ & 1,896 \\
\hline
\end{tabular}

a. Predictors: (Constant), LTDtER, DAR, DER

b. Dependent Variable: Abs

Based on the results in this study, the capital structure variable measured using Debt to Asset Ratio (DAR) has a negative regression coefficient, this means that DAR has a negative and significant effect on the company's financial performance that is projected with Return on Equity (ROE). This is indicated by the significance value of 0.001 . This significant value is smaller than the alpha value of 0.05 . This result is in accordance with capital structure theory, that the greater the debt will have an impact on the decline in company performance, this is because debt has a fixed burden that must be met, namely interest.

Based on the results of this study, the capital structure variable measured using Debt to Equity Ratio (DER) has a negative and significant effect on the financial performance of a company projected with Return on Equity (ROE). This is illustrated by the significance value of 0,000 . Significant value of 0,000 is smaller than the significance value of alpha of 0.05 . Companies with a high debt to equity ratio will have a tendency to decrease in profitability. A high DER ratio will cause the company's risk to be high too.

Based on the results of this study, the capital structure measured by the Long Term Debt to Equity Ratio (LTDtER) has a positive but not significant effect on the financial performance of the company projected with Return On Equity (ROE) at alpha 0.05. While at alpha 0.1 percent, the Long Term Debt to Equity Ratio (LTDtER) has a positive and significant effect on the financial performance of a company projected with Return on Equity (ROE). This is indicated by a significant value of 0.056 . Return on Equity (ROE) The insignificance of LTDtER to ROE can be seen from the average value of LTDtER of 0.19 with a standard deviation of 3.31 , this indicates an uneven distribution between short term debt and long term debt. In other words, in this telecommunications industry, companies use more short term debt compared to long term debt. 
Accounting, $5 \quad(1-18) \quad$ 1946-052. http://dx.doi.org/10.5296/ajfa.v5i2.3740 acesssed on 22 april $\underline{2019}$.

[9] Andreas Michael Holiwono. 2016. Pengaruh Struktur Modal Terhadap Kinerja Keuangan Perusahaan Sektor Manufaktur Sub Sektor Makanan Dan Minuman Yang Terdaftar Di Bei (jurnal) http://repository.unhas.ac.id/handle/123456789/17475. accessed on 5 may 2019

[10] Fajar Ashhiddiqi, Nur Diana, Afifudin. 2016. Analisis pengaruh struktur modal terhadap profitabilitas pada perusahaan LQ45 yang terdaftar di bursa efek Indonesia (jurnal)

http://webcache.googleusercontent.com/search?q=cache:leAxt 6iZTMUJ:riset.unisma.ac.id/index.php/jra/article/download/92 $\underline{8 / 920+\& \mathrm{~cd}=1 \& \mathrm{hl}=\mathrm{id} \& \mathrm{ct}=\mathrm{clnk} \& \mathrm{gl}=\mathrm{id}}$. Accessed on 5 may 2019.

[11] Fauzi, Fitriya, Abdul Basyith, Dan Darius Antoni.2018.Statistik. Depok : PT Rajagrafindo Persada. companies listed on the Indonesia Stock Exchange (IDX); (3) Long Term Debt to Equity Ratio (LTDtER) has a positive but not significant effect on profitability (ROE) of telecommunications industry companies listed on the Indonesia Stock Exchange (IDX); (4) Debt to Asset Ratio (DAR), Debt to Equity Ratio (DER) and Long Term Debt to Equity Ratio (LDER) have a significant influence on the profitability variable (ROE) of telecommunications industry companies listed on the Indonesia Stock Exchange (IDX).

\section{REFERENCES}

[1] Hendraningrat, Denny and Setiawan, Deni (2017). Roadmap Broadband Indonesia Menuju Era Teknologi 5G. Jakarta: Elex Media Komputindo.

[2] Kasmir.2018. Analisis Laporan Keuangan. Edisi 1,cetakan 10. Depok : Rajawali Pers.

[3] Musthafa. 2017. Manajemen Keuangan. Yogyakarta: CV. Andi Offset

[4] Agus, R. Sartono. 2010. Manajemen Keuangan Teori Dan Aplikasi. Edisi Keempat. Yogyakarta : BPFE

[5] Pontororing Marusya dan Mariam Magantar.2016. Pengaruh Struktur Modal Terhadap Profitabilitas Pada Perusahaan Tobacco Manufacturers Yang Terdaftar Di Bursa Efek Indonesia (Bei) Periode 2008-2015.

[6] Marlina Widiyanti, Friska Dwi Elfina. 2015. Pengaruh Financial Leverage Terhadap Profitabilitas Pada Perusahaan Sub Sektor Otomotif Dan Komponen Yang Terdaftar Di Bursa Efek Indonesia https://ejournal.unsri.ac.id/index.php/jmbs/article/view/3343.

Acessed on 22 april 2019

[7] Vudha Wisnala, Purbawangsa, Ida Bagus Anom. 2014. Pengaruh Struktur Modal Terhadap Profitabilitas Sebelum Dan Setelah Krisis Global

[8] Fitriya Fauzi, Abdul Basyith dan Muhammad Idris. 2013. The Determinats of Capital Structure : An Empirical Study of New Zeland-Listed Firms. Asian Journal of Finance \& 